\title{
Social Entrepreneurship and Business Ethics: Does Social Equal Ethical?
}

\author{
Elizabeth Chell • Laura J. Spence • Francesco Perrini • \\ Jared D. Harris
}

Published online: 20 November 2014

(C) Springer Science+Business Media Dordrecht 2014

\begin{abstract}
This editorial to the special issue addresses the often overlooked question of the ethical nature of social enterprises. The emerging social entrepreneurship literature has previously been dominated by enthusiasts who fail to critique the social enterprise, focusing instead on its distinction from economic entrepreneurship and potential in solving social problems. In this respect, we have found through the work presented herein that the relation between social entrepreneurship and ethics needs to be problematized. Further, we find that a range of conceptual lenses and methodological approaches is valuable as the social entrepreneurship field matures.
\end{abstract}

Keywords Social entrepreneurship $\cdot$ Ethics $\cdot$ Social innovation $\cdot$ Scaling

\section{E. Chell}

Small Business Research Centre, Kingston University, London, UK

e-mail: E.Chell@kingston.ac.uk

\section{J. Spence $(\bowtie)$}

Centre for Research into Sustainability, Royal Holloway

University of London, London, UK

e-mail: Laura.Spence@rhul.ac.uk

\section{F. Perrini}

SIF Chair of Social Entrepreneurship \& Philanthropy, SDA Bocconi School of Management, Bocconi University, Milan, Italy

e-mail: francesco.perrini@unibocconi.it

\section{J. D. Harris}

Olsson Center for Applied Ethics, Darden School of Business, University of Virginia, Charlottesville, USA

e-mail: harrisj@darden.virginia.edu
There are practical, theoretical and profound philosophical reasons why deepening our understanding of social entrepreneurship is important (Chell 2007). Practically speaking, when economic systems are in or just emerging from recession, they tend to laud entrepreneurship as a vehicle to provide ready solutions to economic woes, emphasizing entrepreneurship's concern to take products or services to market and generate value. In addition, over the past decade governments, academics and practitioners have begun to place greater emphasis on social entrepreneurship. These activities imply that the products, services and outcomes of the entrepreneurial innovative process have a social value beyond the direct effects on the transactional parties. Theoretically, there is a need to develop sound models of how such initiatives and processes might function, how they might be supported in order to work more effectively, and to identify the key constraining factors. Zahra et al. (2009) provide an excellent starting point for understanding different kinds of social ventures, their associated processes for identifying relevant opportunities and the motivations of social entrepreneurs.

In this special issue, we have attracted contributions from both the ethics and the entrepreneurship perspectives, and we would anticipate the readership to be similarly diverse. Thus, in this editorial, we cover some basic ground from each field in anticipation that this will cover known territory for some but be new for others. We begin our discussion with a summary of key concepts and, in doing so, point to some of the key works and protagonists on social entrepreneurship.

\section{On Conceptual Clarity}

Kickul et al. (2013) note that Social Entrepreneurship (SE), like its parent Entrepreneurship, has suffered the imponderable 
challenges of clarification, definition and differentiation. Protagonists have offered different approaches, e.g. Austin et al. (2006) have compared SE with Entrepreneurship and identified four key differences: the nature of emergent opportunities; differences in mission; differences in resource mobilisation and management and performance measurement especially of social impact. Further, Weerwardena and Mort (2006) have approached an understanding of the characteristics of Social Enterprises from a small case-based study of predominant characteristics that shape actions; environmental dynamics, innovativeness; proactiveness, risk management; sustainability; opportunity-seeking/recognition and social mission. This appears to be so like the characteristics of Economic Enterprises-EEs — with only social mission as the apparent differentiator (although some researchers have disputed that the nature of the mission is necessarily so pure). The creation of social value per se is not in dispute but the approach, means, method and outcomes are. Thus, some authors have talked of a continuum between SE (not-for-profit) and Economic Enterprises (for-profit) (Dees 1998; Chell 2007). Furthermore, if the mission and motives are "impure" then this potentially raises a number of ethical issues and questions. More recently, Dacin et al. (2011) have acknowledged social value creation, defined as the primary mission of social entrepreneurship, as the most promising approach to set the boundaries around the concept.

Focusing more closely on the social perspective, Bacq and Janssen (2011), in reviewing various definitions of social entrepreneurship, stress the ideas of a visionary or innovative approach; a strong ethical fibre; an ability to detect opportunities (to address a social need); with a social entrepreneur as change agent and a mission to make a difference. In this special issue, Sophie Bacq, Brigitte Hoogendoorn and Chantal Hartog build on this earlier work and compare the profiles of economic and social entrepreneurs highlighting from empirical research, the finding that both social and economic entrepreneurs have mixed objectives (cf. Chell 2007).

Clearly, social entrepreneurship is by no means a simple concept. Indeed, according to Choi and Majumdar (2014), it is complex, contested and may be conceived as a cluster of related constructs. It thus behoves us as researchers to consider this complexity before embarking upon research in social entrepreneurship and its complexity our objectives, orientation to and specific interpretation of the construct. Within social value creation, Choi \& Majumdar argue that there are four sub-concepts: social innovation, social enterprise organization, market orientation and the social entrepreneur. In this special issue, we address these various aspects. While the creation of social value is a necessary condition of social entrepreneurship, it is the combination of social value creation with other elements that together constitute social entrepreneurship. Hence, to research and frame the ethical nature of social entrepreneurship, it is crucial to have a depth of understanding of the nature of the social value created and how it is assessed or measured. The cluster may then serve as a conceptual tool for advancing our shared understanding of the nature of social entrepreneurship, social entrepreneurs, social innovation, the markets they enter and how they are organised. Further, we should not presume that the social enterprise is set up to "do good" in simplistic terms, but examine critically how it is organised, with what intentions and outcomes.

Definitions of social responsibility and related topics are contested (Lockett et al. 2006), but in order to proceed with some clarity, broadly speaking, business ethics is understood as the everyday moral rules-in-use in organizations (Jackall 1988). Social responsibility is those expectations on business organizations beyond pecuniary ones (Carroll 1999). In this special issue, we want to show that both ethical and social lens' should be employed to understand social enterprises. Regular readers of the Journal of Business Ethics will be familiar with different ethical perspectives, but for the sake of those who are starting from an entrepreneurship lens, it is perhaps worth identifying the key ethical frameworks that have been employed for instance in related research. Spence (2014a) elaborates on these in her work on small- and medium-sized enterprises, proposing that the key ethical frameworks employed include research from the classical works of Kant (to do one's duty according to reasoned consideration); utilitarianism (to act according to foreseen consequences and maximise utility for all); egoism (to act in one's own selfinterest); social contract theory (focusing on a socially agreed set of rules that govern society and emphasise rights and justice); virtue ethics (judging the character of the individual); to more contemporary theories, such as discourse ethics (which focuses upon decision-making, the resolution of conflicts, power differentials and empathetic understanding); postmodern ethics (in which ethics is selfdetermined rather than the observance of a prescribed set of ethical codes); moral intensity (an issue-dependent model of decision-making, which can be used to evaluate different ethical situations); and the ethic of care (which focuses upon the interconnectedness of people and the social dimension, and the responsibility of the 'self' in caring for the 'other'). Examples of how these have been employed in small business ethics research are reviewed in Spence (2014a, b), and the articles in this special issue make valuable contributions in developing some of these approaches. It is perhaps noteworthy that on the whole, they emphasise less the traditional, principle and justice based theories, and tend more towards postmodern and critical approaches. Thus, in this Special Issue, Pascal Dey and Chris Steyaert adopt a postmodern, radical humanist, approach to ethics based on the work of Foucault. Haugh and Alka Talwar assume radical humanist assumptions in 
their paper, and André and Pache draw on the ethic of care (see also Spence 2014b). Taking somewhat more familiar routes for the business ethics field, Brett Smith, Geoffrey Kistruck and Benedetto Cannatelli assume an ethical framework based on moral intensity, and Begoña Gutiérrez-Nieto, Carlos Serrano-Cinea and Juan Camón-Cala draw on ethical decision-making frameworks. Sophie Bacq et al. turn to altruism, while Sandra Waddock and Erica Steckler focus on vision, values and beliefs.

Aside from their individual perspectives, our papers contribute to three overarching themes which we will elaborate here. These relate to the links between social entrepreneurship, ethics and the social; ethical aspects of scaling and measuring social capital; and ethics and social entrepreneurial outcomes.

\section{On the Links Between Social Entrepreneurship, Ethics and the Social}

The progress made in social entrepreneurship research has not been matched by a robust analysis from the ethics perspective (Cornelius et al. 2008). There is a presumption that because something is socially-oriented, the motivation is likely to be ethically sound; that it is principled, morally justified and ethically legitimate. We contend that this is superficial shorthand, and part of the role of the Journal of Business Ethics and similar publications must be to critique, explain and assess the ethics of social enterprises in the same way as we do other organizations. Hence, the question at the heart of this endeavour is as follows: Is the social inherently ethical? In this article and the selection of papers which make up the special issue, we conclude that there is considerable need to research further the ethical context of social entrepreneurship and enterprise.

The framing of social entrepreneurship from a disciplinary perspective raises a number of issues (Perrini 2006). Ridley-Duff and Bull (2011) distinguish between economic, social and ethical capital. An economic approach opens the question of a blurring of the difference between profit and not-for-profit social enterprises (Chell 2007); the motivations of social entrepreneurs; the impact of the market mechanism on business decision-making, weakening an ethical approach and raising concerns about the inadequacy of the neo-classical economic approach to business. The issues have tended to highlight relationships, at individual-level, within the enterprise and with the community. This suggests the need to consider the social embeddedness of social and socially innovative enterprises (Jack and Anderson 2002) with ethical concerns comprising trust, cooperation and commitment relations (Bull et al. 2008; Seanor and Meaton 2008).
A key common feature of the articles we present here is that they all draw from a wide range of literature sources, somewhat outside of the 'usual suspects' for Journal of Business Ethics article. This is something we support and have encouraged, since we think that this topic like many others suffers from somewhat of a silo mentality with research developing apace in different sub-disciplines with only limited cross-referencing and learning. For instance, some learning can be drawn from research on ethics in small business, since social enterprises are often also smaller organizations (Spence and Rutherford 2003; Moore and Spence 2006; Morsing and Perrini 2009). Entrepreneurship is a similarly fruitful pool from which to draw. Indeed, as long ago as 1985, Kets de Vries wrote on The Dark Side of Entrepreneurship, which has some salience here. In a special issue published by the Journal of Business Venturing, Harris et al. (2009) sought to map out the ethical issues and their social implications in the field of Entrepreneurship generally. A special issue of the Journal of Business Ethics (Pless 2012) did sterling work of bringing social enterprise into the business ethics literature, but emphasised the social enterprise side of the debate rather than the ethics. In this special issue, we go beyond these somewhat polarised approaches and lay the basis, through the papers, for a more stable foundation which integrates social enterprise and ethics.

Two of our papers, by Pascal Dey \& Chris Steyaert and Helen Haugh \& Alka Talwar, deal with our question about whether the social is inherently ethical, head-on. The first draws on sociological perspectives on power, subjectivity and freedom and problematizes the context of much of the superficial assumptions around the authentic nature of the practice of social entrepreneurship. Using the work of Michel Foucault, they conclude that a practice-based approach of ethics is a suitable way to advance our understanding of how social entrepreneurs can create conditions of freedom without pre-supposing a 'true self' or glibly ethical expectation. They focus on power at the micro-, individuallevel in contrast to work that concentrates on hegemony at meso-/macro-levels. They argue that ethics of social entrepreneurship is emergent, realised through social actions that struggle with power, subjectivity and freedom. Social entrepreneurs are not inherently moral beings who do the right thing in contrast to the rest. This would give the social entrepreneur a persona of moral superiority: an essentialist view that is challenged. Thus, Dey and Steyaert seek to answer the question; if social entrepreneurs are not innately ethical, how do they come to enact goodness and social good that others value? Indeed one might ask whether all social entrepreneurs enact such goodness? Dey and Steyaert ask how social entrepreneurs overcome external powers and pressures to conform to a model of economic behaviour (within the strictures of capitalism) that will enable them to live an ethical life. Crucial, argues Foucault, is freedom 
juxtaposed against the forces of repression, preserving the ability to make choices about what to do and who to be; hence, there ensues a tussle with one's subjectivity and the sense of freedom needed to realise one's objectives.

Reflecting discussions well embedded in the corporate social responsibility literature around positive social change (Aguilera et al. 2007), the article by Helen Haugh and Alka Talwar focuses on the importance of the constructs of empowerment-in particular of women-and changing social norms to produce an innovative framework for Emancipatory Social Change. This in turn links to work on emancipatory entrepreneurship (Goss et al. 2011) which, similarly to the Dey and Steyaert paper, understands the sociological perspective on power through practice. As empirical basis for their work Haugh and Talwar draw on Mahaul, a rural social enterprise in North India which sells traditional handicraft products made by women in rural villages. They argue that emancipatory social entrepreneurship can be a vehicle for social change by empowering women in socio-cultural milieu where the role of women is circumscribed by cultural norms of patriarchy, limiting their education and scope to develop themselves, and allowing them the freedom to support their families by working outside the home. The article demonstrates how emancipatory social entrepreneurship business models and processes are designed to enable women to overcome the barriers that constrain their freedom, by such means as the development of the women's networks, their skills, and their literacy. The ethical dimension is specifically based on the premise that empowerment-economic and cultural freedom-is good for the women concerned. However, critical reflection suggests that this may be gained at a price. Some women faced resistance from within the family although some husbands were supportive; this resistance could also be felt in the wider community. Hence, there were personal risks if the venture failed. This market-based system of emancipation is clearly embedded in the capitalist system, and these authors raise the fundamental question as to whether, in rural communities, capitalism is in the interests of developing countries and the poor. Haugh \& Talwar stress in their conclusion that empowerment is not a purely female construct, and that there is a considerable work not least across a range of gendered social enterprises (e.g. rehabilitation of male offenders) which will further our understanding of social entrepreneurship, ethics and social change.

\section{On Ethical Aspects of Scaling and Measuring Social Entrepreneurship}

There has been a considerable gap in our understanding of ethical implications in relation to opportunity recognition, scaling social entrepreneurship, measuring social contribution and the market mechanism. Three of the articles in this special issue address these problems. Papers by Kevin André \& AnneClaire Pache and Brett Smith et al. address scaling from intriguingly different ethical perspectives.

Andre \& Pache draw on the ethic of care. They take a view of social entrepreneurs as caring entrepreneurs, and extend this through the entrepreneurial process to encompass opportunity recognition and filtration, creation and exchange in terms of caring about, taking care of, care giving and care receiving. Within the process of scaling up, social entrepreneurs turn their attention to resource providers and other stakeholders, and run the risk of diluting the care offered to beneficiaries. Moreover, with the growth of the enterprise comes greater bureaucratisation, including rationalisation and standardisation to ensure the efficient use of scarce resources. This development poses further ethical challenges on the shoulders of the social entrepreneurs. It presents the complex risk of ceasing to care. Moreover, in assessing impact, the social entrepreneur may no longer focus on the disposition of caring in the need to establish measurable results, and what is at stake is their ethical integrity. The authors put forward a five-point plan to help maintain the ethic of care in the scaled-up organization and by that token avoid mission drift. The article by André and Pache chimes with research around small business social responsibility and the care perspective (Spence 2014b; von Weltzien Høivik and Melé 2009), suggesting some wider application too.

Smith, Cannatelli \& Kistruck, in contrast, take a more conventional ethical decision-making lens to understand the influence of moral intensity in scaling social impact. This also complements work in the ethics and small business field, which draws out the aspect of proximity in moral intensity as especially important (Lähdesmäki and Suutari 2012). Smith, Cannatelli \& Kistruck develop a model of scaling social impact which suggests that the entrepreneurs desire for control, moral intensity and the organizational mode of scaling positively influence the scaling of social impact. The argument revolves around the moral intensity of the situation; the greater the moral intensity, the greater the imperative to take action. Moral intensity concerns the magnitude of consequences, the degree of social agreement about the moral content of the issue, the likelihood that the issue will result in bad or good, the relative immediacy of the consequences, proximity to the consequences and the magnitude of the impact (number of people affected). Implicit (but unknown) according to these authors is the ethical characteristics of the social entrepreneur and the decision not only to start a particular social venture but also to scale it up. In this regard, it begs the question posed by Waddock and Steckler of what is the vision and how did it arise. Further, the mode by which social entrepreneurs choose to scale their enterprise has ethical implications. 
The different modes suggest different degrees of control exerted by the founding social entrepreneur. This need for power suggests an egotistical 'dark side' to both economic and social entrepreneurs (de Vries 1985).

The article by Begoña Gutiérrez-Nieto, Carlos SerranoCinca \& Juan Camón-Cala presents a further useful contribution to the debate around measurement, identifying a credit scores system of socially responsible lending. The paper moves beyond traditional approaches around socially responsible lending to incorporate a focus on social impact which is just as complex as the mechanisms commonly used for financial impact. They propose a model for social credit score based on applicant credit history, the present situation of the company and financial and social viewpoints of the specific project. One of the five sets of criteria includes a social impact assessment, a history of the enterprise and intangibles that include human, internal and external capital. The upshot is a balanced score card which reveals the strengths and weaknesses of the application. This demonstrates how a socially responsible lender can quantify both financial and social impact criteria to assess an applicant according to the lender's own values whether that be impact on employment, equality, community outreach or other socially valued criteria. There is considerable room for further work on measuring social impact not least in the sphere of social entrepreneurship but also more generally for government and business initiatives too.

\section{On Ethics and Social Entrepreneurial Outcome}

In our final section of papers, the person of the entrepreneur herself is more directly focused upon especially in terms of the social entrepreneur's position in relation to social entrepreneurial outcome. Both papers presented here robustly challenge the binary assumptions of cause and effect in research on social entrepreneurs.

Sophie Bacq, Chantal Hartog \& Brigitte Hoogendoorn take a critical approach to the assumptions made about social entrepreneurs using quantitative data from the Global Entrepreneurship Monitor. They proffer a series of questions concerning the nature of empathy and moral judgement of social entrepreneurs and the observation that it would appear that social entrepreneurs project a fragile entrepreneurial profile and as such may be less likely to achieve their mission. Finally, they speculate as we have mentioned above that social entrepreneurs' motives could be "impurely altruistic". Thus, the article by Bacq et al. seeks to go beyond the taken-for-granted moral portrayal of social entrepreneurs which we started this article with, that is, that social entrepreneurs are ethical. Indeed, they give an intriguing and counter-intuitive answer to the question of the link between ethics and the social entrepreneur. They find that in contrast to the dominant idea that a strong entrepreneurial orientation is a source of ethical approach, they find that the reverse is true. In short, Bacq, Hartog \& Hoogendoorn have evidence that ethical issues are also likely to emanate from a frail entrepreneurial profile. This startling re-buff to the rose-tinted way in which much of the media portray social entrepreneurship is an important and timely intervention.

Our special issue ends by coming back to a broad view of an element of the social entrepreneur's life and the literature and media buzz around social entrepreneurship: the much-maligned concept of 'vision'. Sandra Waddock and Erica Steckler present qualitative work on the narrative life stories of social entrepreneurs, which highlights the interactive nature of vision, linking it in different ways to action. They theorise three possible courses taken by social entrepreneurs: (a) deliberate or purposive, where vision is an outgrowth of intention which precedes action; (b) vision arises from action either inadvertently where there is an aspiration but no clear pathway, and it is gradually through immersion in their work that a vision, though not necessarily a coherent vision, emerges, or (c) vision is emergent or developmental, arising through actions based on their values and beliefs to make a difference in the world, a vision gradually emerges in an evolutionary fashion. Hence, we may conclude from this article that some social entrepreneurs' work may be imbued by a moral set of values from the outset but that this does not apply to all. In short, Waddock and Steckler find that it is not necessarily the case that vision precedes action in entrepreneurship.

\section{Conclusion}

Entrepreneurship has been bedevilled with myths-the heroic male who goes it alone against the odds; the entrepreneur who happens to be in the right place at the right time; the notion that anyone can be an entrepreneur-and now we can add potentially the myth concerning the ethical social entrepreneur. Our stated aim in our call for contributions to this Special Issue was to garner evidence to explode what appeared to be a misapprehension about the nature of social entrepreneurs and social entrepreneurship. Certainly there is room for social entrepreneurs to identify a social need as a problem that their enterprise might address (though the social need might simply be construed as a business opportunity and the motives might be mixed); and whilst it may be possible to develop an ethical framework around that enterprise going forward there is no inevitability about this, as several of our papers clearly demonstrate. Further, the notion that the ethical pursuit of a social issue might simply continue when there are numerous pressures pulling the enterprise in other directions is unrealistic. What we have 
found is that whatever the social entrepreneur's original motives the obstacles to be overcome, the developmental issues arising, the need for different capitals, especially financial, and the relationships engendered; all may contribute to mission drift.

We have also found that the pursuit of social enterprise solutions tends to be intertwined with social innovations within their processes and practices. The work raises some fascinating questions: What does it mean to be a social entrepreneur? Why are women more likely to be social entrepreneurs and what is it about empathetic understanding that facilitates the pursuit of social entrepreneurship and does this same quality assure successful outcomes? What are the different ways in which scaling-up social enterprises can be successfully achieved and how can social enterprises maintain an ethical stance in a capitalist environment where there may be pressures to compromise in order to pursue a sustainable course? What are the different ways in which social enterprises can deal with intangible aspects of the environment, in particular power and cultural norms, and how can this be carried out ethically? Further how, in a capitalist system, can social enterprises be funded ethically such that the greater good and social outcomes are shown to be achieved and are achievable? The articles in this special issue begin to address all these questions, but there is still more work to be done.

The research methods in evidence in respect of social entrepreneurship tend to be conceptual, theory-building, qualitative and exploratory around single case studies. We are pleased to be contributing to a broadening of methodological approaches, but much more work should be done on this.

The scholarship drawn upon in this volume tends to be Western, in particular European and North American. There is thus a need for research from Asia, Africa and South America to give a broader picture of social entrepreneurship in other geographical locations and internationally and locally embedded situations.

Finally, we hope to have contributed to the maturing of the social entrepreneurship field by adding a range of critical scholarly perspectives which demonstrate at the very least that we need to continually investigate the links and fissures between the social and the ethical and better understand the implications of the assumptions which underpin policy, practice and scholarship around social entrepreneurship.

\section{References}

Aguilera, R. V., Rupp, D. E., Williams, C. A., \& Ganapathi, J. (2007). Putting the $\mathrm{S}$ back in corporate social responsibility: A multilevel theory of social change in organizations. Academy of Management Review, 32(3), 836-863.
Austin, J., Stevenson, H., \& Wei-Skillern, J. (2006). Social and commercial entrepreneurship: Same, different, or both? Entrepreneurship, Theory \& Practice, 30(1), 1-22.

Bacq, S., \& Janssen, F. (2011). The multiple faces of social entrepreneurship: A review of definitional issues on geographical and thematic criteria. Entrepreneurship \& Regional Development, 23(5-6), 373-403.

Bull, M., Ridley-Duff, R., Foster, D., Seanor, P. (2008). Seeing social enterprises through the conceptualisation of ethical capital. Paper presented at the ISBE Conference, 5-7 November. N. Ireland: Belfast.

Carroll, A. (1999). Corporate social responsibility: Evolution of a definitional construct. Business and Society, 38(3), 268-295.

Chell, E. (2007). Social enterprise and entrepreneurship: Towards a convergent theory of the entrepreneurial process. International Small Business Journal, 25(1), 3-19.

Choi, N., \& Majumdar, S. (2014). Social entrepreneurship as an essentially contested concept: Opening a new avenue for systematic future research. Journal of Business Venturing, 29(3), 363-376.

Cornelius, N., Todres, M., Janjuha-Jivraj, S., Woods, A., \& Wallace, J. (2008). Corporate social responsibility and the social enterprise. Journal of Business Ethics, 81, 355-370.

Dacin, M. T., Dacin, P., \& Tracey, P. (2011). Social entrepreneurship: A critique and future directions. Organization Science, 22(5), 1203-1213.

De Vries, K. (1985). The dark side of entrepreneurship. Harvard Business Review, 85, 160-168.

Dees, J. G. (1998). Enterprising nonprofits. Harvard Business Review, $76,55-67$.

Goss, D., Jones, R., Betta, M., \& Latham, J. (2011). Power as practice: A micro-sociological analysis of the dynamics of emancipator entrepreneurship. Organization Studies, 32(2), 211-229.

Harris, J. D., Sapienza, H. J., \& Bowie, N. E. (2009). Ethics and entrepreneurship. Journal of Business Venturing, 24, 407-418.

Jack, S. L., \& Anderson, A. R. (2002). The effects of embeddedness on the entrepreneurial process. Journal of Business Venturing, 17, 467-487.

Jackall, R. (1988). Moral mazes: The world of corporate managers. New York USA and Oxford, UK: Oxford University Press.

Kickul, J., Gras, D., Bacq, S., \& Griffiths, M. (2013). Introduction. In J. Kickul, D. Gras, S. Bacq, \& M. Griffiths (Eds.), Social entrepreneurship (Vol. 1). Cheltenham UK, Northampton, MA, USA: Edward Elgar.

Lähdesmäki, M., \& Suutari, T. (2012). Keeping at arm's length or searching for social proximity? Corporate social responsibility as a reciprocal process between small businesses and the local community. Journal of Business Ethics, 108(4), 481-493.

Lockett, A., Moon, J., \& Visser, W. (2006). Corporate social responsibility in management research: Focus, nature, salience and sources of influence. Journal of Management Studies, 43(1), $115-136$.

Moore, G., \& Spence, L. J. (2006). Responsibility and small business: Editorial. Journal of Business Ethics, 67(3), 219-226.

Morsing, M., \& Perrini, F. (2009). CSR in SMEs: do SMEs matter for the CSR agenda? Business Ethics: A European Review, 18(1), $1-6$.

Perrini, F. (2006). The new social entrepreneurship: What awaits social entrepreneurial ventures. Cheltenham: Edward Elgar.

Pless, N. M. (2012). Social entrepreneurship in theory and practice: An introduction. Journal of Business Ethics, 111(3), 317-320.

Ridley-Duff, R., \& Bull, M. (2011). Understanding social enterprise. London: Sage.

Seanor, P., \& Meaton, J. (2008). Learning from failure, ambiguity and trust in social enterprise. Social Enterprise Journal., 4, 21-40. 
Spence, L. J. (2014a). Business ethics and social responsibility in small firms. In E. Chell \& M. Karataş-Özkan (Eds.), Handbook of research on small business and entrepreneurship. Cheltenham, UK; Northampton, MA, USA: Edward Elgar.

Spence, L. J. (2014b). Small business social responsibility: Redrawing core CSR theory. Business and Society,. doi:10.1177/ 0007650314523256.

Spence, L. J., \& Rutherford, R. (2003). Small business and empirical perspectives in business ethics: An editorial. Journal of Business Ethics, 47, 1-5.
Von Weltzien Høivik, H., \& Melé, D. (2009). Can an SME become a global corporate citizen? Evidence from a case study. Journal of Business Ethics, 88(3), 551-563.

Weerwardena, J., \& Mort, G. S. (2006). Investigating social entrepreneurship: A multidimensional model. Journal of World Business, 41, 21-35.

Zahra, S. A., Gedajlovic, E., Neubaum, D. O., \& Shulman, J. M. (2009). A typology of social entrepreneurs: Motives, search processes and ethical challenges. Journal of Business Venturing, $24,519-532$. 